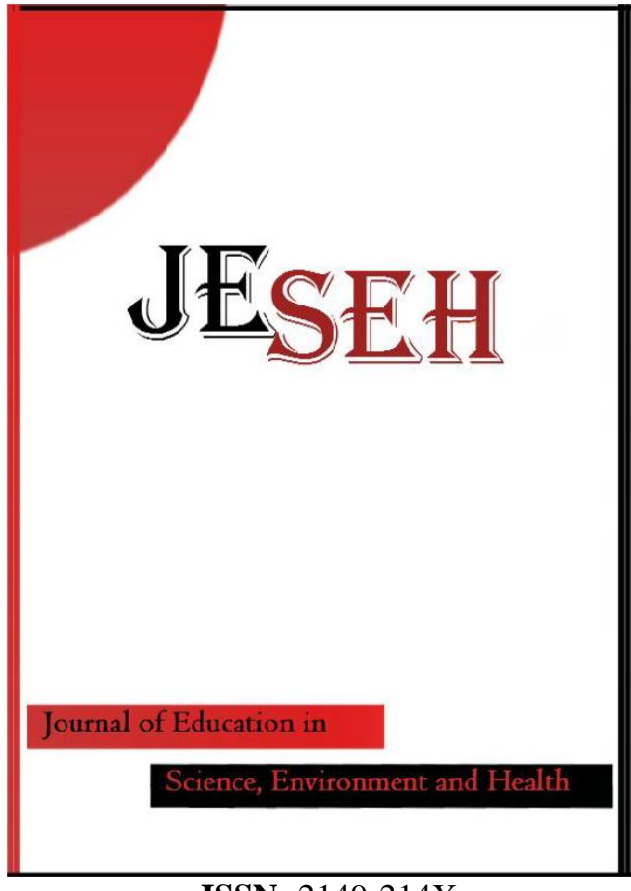

ISSN: $2149-214 \mathrm{X}$

\section{Journal of Education in Science, Environment and Health}

\section{www.jeseh.net}

\section{Improving Elementary School Teacher Candidates' Views of Nature of Science Through Intensive Education}

Tugba Ecevit, Yalcin Yalaki, Sevgi Kingir

Hacettepe University

To cite this article:

Ecevit, T., Yalaki, Y., \& Kingir, S. (2018). Improving elementary school teacher candidates' views of nature of science through intensive education. Journal of Education in Science, Environment and Health (JESEH), 4(2), 155-171. DOI:10.21891/jeseh.432524

This article may be used for research, teaching, and private study purposes.

Any substantial or systematic reproduction, redistribution, reselling, loan, sub-licensing, systematic supply, or distribution in any form to anyone is expressly forbidden.

Authors alone are responsible for the contents of their articles. The journal owns the copyright of the articles.

The publisher shall not be liable for any loss, actions, claims, proceedings, demand, or costs or damages whatsoever or howsoever caused arising directly or indirectly in connection with or arising out of the use of the research material. 


\title{
Improving Elementary School Teacher Candidates' Views of Nature of Science through Intensive Education
}

\author{
Tugba Ecevit, Yalcin Yalaki, Sevgi Kingir
}

\begin{tabular}{|c|c|}
\hline Article Info & Abstract \\
\hline Article History & \multirow{8}{*}{$\begin{array}{l}\text { Elementary school teacher candidates' (student teachers or STs) views of nature } \\
\text { of science are important for an effective science teaching that aims to improve } \\
\text { children's scientific literacy. The purpose of this study was to improve STs' } \\
\text { views of nature of science through an intensive intervention. The study group } \\
\text { consisted of } 65 \text { third year STs who were attending a major university in Ankara } \\
\text { Turkey during the } 2015 \text { - } 2016 \text { fall semester. An educational program with a } \\
\text { variety of activities that were designed to help improve participants' views of } \\
\text { nature of science was applied and the effect of this program was evaluated. The } \\
\text { educational program included historical approach activities, generic activities, } \\
\text { explicit-reflective approach activities, and media news analysis activities which } \\
\text { were applied in three hour periods over the course of nine weeks. Both } \\
\text { qualitative and quantitative data were collected in this convergent parallel mixed } \\
\text { method study. At the beginning of the study, the participating STs had naive } \\
\text { views of nature of science and some misconceptions. After the applied } \\
\text { educational program, STs' views of nature of science improved and they adopted } \\
\text { more contemporary views of science. As a result, a long-term intervention with } \\
\text { multiple methods of teaching with different kinds of activities was found to be an } \\
\text { effective approach for improving STs' understanding of nature of science. }\end{array}$} \\
\hline $\begin{array}{l}\text { Received: } \\
\text { 14 September } 2017\end{array}$ & \\
\hline $\begin{array}{l}\text { Accepted: } \\
\text { 02 June } 2018\end{array}$ & \\
\hline Keywords & \\
\hline Nature & \\
\hline & \\
\hline & \\
\hline rvention & \\
\hline
\end{tabular}

\section{Introduction}

In the 21 st century, the amount of scientific knowledge increases exponentially and technology advances very fast which pose challenges to the general public. These fast advancements in science and technology increase the importance of educating people with skills and experience to deal with such challenges. In Turkey and in many countries around the world, improving science education for the purpose of preparing citizens with the required skills of the 21st century is an ongoing effort. In today's world, using knowledge is a more important skill than searching or finding knowledge. Accordingly, the most important purpose of today's science education is to educate individuals to become scientifically literate (American Association for the Advancement of Science [AAAS], 1990; National Research Council [NRC], 1996, 2011; Ministry of National Education [MNE], 2013, 2017; NGSS Lead States, 2013; The Organization for Economic Co-operation and Development [OECD], 2015). Turkey, like other developing countries, ascribes importance to science education, which is seen as a key to develop the nation's economy. To serve this purpose, new science education curriculums are prepared to educate individuals who can create new knowledge and make important discoveries. The Turkish science education curriculum was renewed in 2013 and 2018 and in both curriculum documents, vision was stated as "all students to be trained as scientifically literate individuals" (MNE, 2013, 2018). Nature of science (NOS) is one of the most important dimensions of scientific literacy. For a person to be scientifically literate, his/her understanding of NOS has to be adequate (AAAS, 1990, Çepni, 2011; Lederman, 1992; McComas vd., 2000). However, Program for International Student Assessment (PISA) 2015 results showed that Turkish students' scientific literacy results are significantly lower than the OECD average (OECD, 2015). This is a strong indication that more should be done to improve students' NOS understanding and scientific literacy. Improving teacher education is an obvious place to start to this end.

One of the important subjects of NOS is to explain what science is. Science is an ever changing, developing, multi-dimensional, and complex phenomenon that to agree on a definition of science is very difficult. The $10^{\text {th }}$ grade biology textbook in Turkey define science as "regular knowledge accumulated through objective experiments and observations." This definition proposes a positivist science understanding by suggesting objective observations and experiments are possible. It does not mention scientists' prior knowledge, education, subjective point of view, creativity, and socio-cultural environment which are factors that influence their interpretation of observational and experimental data (Doğan et al., 2012). Similar positivist approaches to 
science and scientific knowledge in educational resources create misconceptions or scientific myths. McComas (1996) reported the following myths that students have about NOS: (i) hypotheses turn into theories, theories turn into scientific laws, (ii) there is a universal scientific method, (iii) scientific method provides certain evidence, (iv) scientific method can answer all questions, (v) scientists are objective, (vi) main way to reach knowledge is experiment, (vii) scientific results are verified experimentation, (viii) scientific knowledge is certain and it's correctness cannot be discussed, (ix) science and technology are similar to each other, (x) science is not a teamwork, it is an individual effort.

Lederman (1992) defined NOS as values and assumptions in the scientific enterprise. McComas and Olson (1998) explained that NOS is about answers given to the questions such as: What is science? How is it done? How do scientists work? What are the effects of scientific and cultural realm on science? Just like the definition of science, there is no consensus on what NOS is. However, to provide a framework for teaching and learning of NOS, a consensus has been reached among some science educators on what students and teachers should know about NOS (Bell et al., 2000; Deboer, 2000; Lederman, 1992; Matthews, 1996). Lederman (2007) listed seven themes to describe the so called "consensus view of NOS." These themes are:

1. Scientific knowledge is tentative: scientific knowledge is stable but it is never certain or absolutely true. Scientific knowledge changes through evolutionary and revolutionary processes. Scientific knowledge may change with new data or reevaluation of existing data.

2. Scientific knowledge is based on evidence: science is based on direct or indirect observation of the natural world. Science is not only based on scientific evidence, it's also based on logical inferences. Scientific knowledge is supported through experimental data but it is never proved. Observation and inference should not be confused with each other. Scientists may have different inferences of same observations.

3. Scientific knowledge involves subjectivity: Scientists' prior knowledge, experience, values and beliefs, education and expectations influence their study and the results they reach.

4. Scientific knowledge is created with creativity and imagination: Scientists use their creativity and imagination in every stage of their scientific work.

5. Science is influenced by the sociocultural environment: Political establishment, social values, economic conditions, and cultural structure influence how, what and to what degree scientists study a subject.

6. Scientific theories and laws: Theories are scientific explanations while laws are scientific descriptions of the natural phenomenon. They serve different purposes in science and there is no hierarchical relationship between them.

7. Scientific method: There is no one universal scientific method that all scientists follow. Many different fields of science use many different methods to produce scientific knowledge.

In this study, we focused on the first four themes since these are the most appropriate for the elementary school level (Lederman \& Lederman, 2005). The study group consisted of elementary school STs and therefore we concentrated our efforts for teaching and learning of the most relevant NOS themes for the elementary level.

In the literature, there are three different approaches to teach this view of NOS: historical approach, implicit approach and explicit-reflective approach. In historical approach, NOS is taught through discussions about how scientific knowledge changed over time and lives of scientists and their work (Khishfe \& Abd-El-Khalick, 2002). Implicit approach is based on the idea that students can learn about NOS while doing inquiry-based activities (Abd-El-Khalick \& Lederman, 2000). In this approach, it is assumed that students can learn NOS as they work like scientists in the classroom. However research has shown that implicit approach is not very effective in teaching NOS (Abd-El-Khalick, 2002; Khishfe \& Abd-El-Khalick, 2002; Lederman, 1992). According to explicit reflective approach, students learn NOS best if it is discussed with students during and after inquiry activities in the classroom rather than waiting for students to figure out what it is for themselves (Abd-El-Khalick \& Lederman, 2000). In this approach, themes of NOS are discussed with students explicitly. Research shows that explicit reflective approaches are more effective in helping children learn about NOS compared to other approaches (Schwartz \& Lederman, 2002; Schwartz et al, 2004).

One of the new approaches in teaching NOS involves using popular media news about science (Çakmakçı \& Yalaki, 2012). Students understanding of NOS can be improved by asking them questions about scientific studies mentioned in printed or visual media such as: What is the scientific claim in this news? What evidence did scientists use to support their claims? What methods of science were mentioned in the news? How science is influenced by the social and cultural environment? Another new approach that is used recently to teach NOS involves using documentary films to help students understand NOS (Seçkin Kapucu \& Çakmakç1, 2015). In this 
approach, systematically planned and used documentary movies are suggested to help students to learn about NOS. Generic activities that are not related to science subjects or science activities have also been used for teaching NOS (Lederman, 2007). However activities that are integrated into science subjects may provide better results, which is a claim that needs to be further investigated.

Although understanding of NOS is considered to be one of the basic elements of scientific literacy, research shows that students, STs, and teachers do not have an adequate understanding of NOS (Abd-El-Khalick \& Lederman, 2000; Aslan, Yalçın \&Taşar, 2009; Doğan \&Abd-El-Khalick, 2008; Doğan et al., 2012; Khishfe \& Abd-El-Khalick, 2002; Köseoğlu, Tümay \& Üstün, 2010; Lederman et al., 2002; Lederman, 1992, 2007; Taşar, 2003). Lederman (2007) argued that the reason why students are not at a desired level in terms of NOS understanding is because of the misconceptions that their teachers have. Within the framework of postmodern arguments that criticized the positivist views of science, todays' understanding of NOS is shaped. However, a naive positivist understanding of science is still at the root of most teachers' misconceptions about NOS (Bell et al, 2003; Lederman, 1992; McComas, 1996). Studies showed that both teachers and STs require in-service and preservice training to improve their understanding of NOS (Lederman, 2007). To improve students', STs', and teachers' understanding of NOS, it should be taught effectively. Research shows that every approach used in teaching of NOS is effective in developing certain themes of NOS understanding and no singe approach is enough to develop all of the NOS themes alone (Lederman, 1992; Lederman et al., 2002; Khishfe \& Abd-ElKhalick, 2002; Khishfe, 2008). Because of this, various approaches of teaching NOS were utilized together in this study to achieve a more effective NOS teaching and learning.

The role of classroom teachers on young children's learning of NOS is obvious. Accordingly, elementary level STs' views of NOS have a direct influence on young students understanding of NOS. If classroom teachers' NOS views can be enriched by contemporary ideas, they may use better strategies in teaching NOS to young students. One of the duties of classroom teachers is to help their students learn NOS appropriately and help them develop an adequate scientific literacy. However, literature review revealed that the number of studies that investigated elementary level STs' understanding of NOS is relatively limited in Turkey (Tatar, Karakuyu \& Tüysüz 2011a, 2011b). Therefore, the purpose of this study was to improve STs' understanding of NOS and how to teach it. As indicated in many studies, different techniques should be applied for an extended period of time to change misconceptions about science (Tuan \& Chin, 1999). For this purpose, a teaching plan, which included multiple approaches of teaching, was developed to improve STs' understanding of NOS. The teaching plan included historical approach activities, generic activities, explicit-reflective approach activities, and media news investigation activities which were applied three hours a week for nine weeks. These approaches to teach NOS were used in the literature by various researchers and they were reported to be effective in teaching certain aspects of NOS (Cakmakci \&Yalaki, 2012; Khishfe \& Abd-El-Khalick, 2002; Michel \& Neumann, 2016; Tolvanen, Jansson, Vesterinen, \& Aksela, 2014). Although there are more approaches to teaching NOS, the chosen methods were a good representation of what is studied in the literature. We investigated the effects of this teaching plan on STs' understanding of NOS.

The intensive intervention that includes a variety of approaches for teaching NOS to ST's is the main characteristic of this study. As Ochanji (2003) indicate, teacher education programs should offer more than a superficial knowledge and understanding of NOS for future teachers to teach it effectively in their classrooms. Teacher education programs should offer examples, cases, context, and pedagogy for teaching and learning of NOS. The contribution of this study is to provide an example of such an effective teacher education program as most studies in the literature offer a single approach to teach NOS.

\section{Problem Situation}

What is the effect of intensive, multiple approach teaching on STs' understanding of NOS?

\section{Sub Problems}

1. What is the STs' level of understanding of NOS before the intervention?

2. How did STs' understanding of NOS changed after the teaching intervention? 


\section{Method}

We used the convergent parallel mixed method design to investigate classroom teacher candidates' ideas about NOS and how to teach it (Creswell \& Plano-Clark, 2011; Mcmillan \& Schumacher, 1997). In this design, qualitative and quantitative data were gathered at the same time. Qualitative and quantitative data were collected and analyzed independently, but results obtained from two types of data were mixed during the overall interpretation. Using a combination of qualitative and quantitative methods enriches research data and enhances validity and reliability of the conclusions derived from the study (Lincoln \& Guba, 1985).

\section{Study Group}

The study group included 65 third year students attending the division of classroom education at a major university in Ankara, Turkey during the 2015 fall semester. The students in the study group were attending a science and technology methods course in which the study took place. The course provided an appropriate context for this study as its aim was to teach STs how to apply certain activities in the science classroom. The attendees of the course were a convenience sample for this study.

\section{Data Collection Instruments}

We used quantitative and qualitative data collection instruments together in this convergent parallel mixed method study.

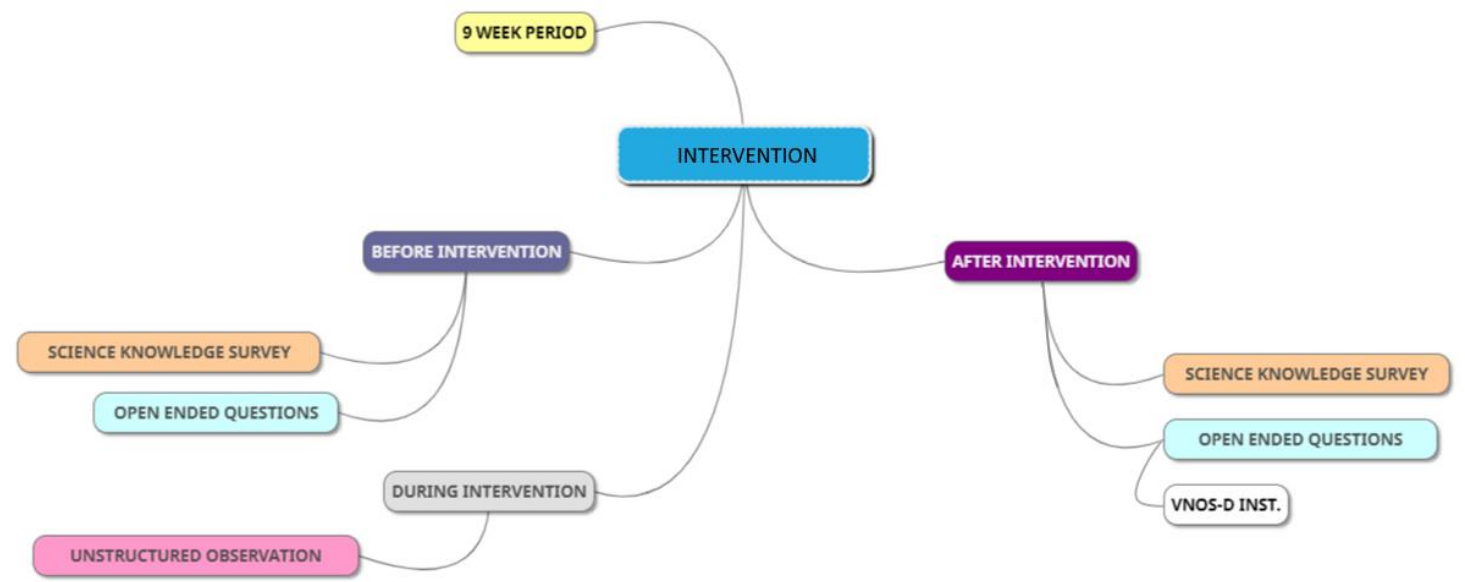

Figure 1. Mind map of data collection instruments before and after intervention

To determine classroom teachers' ideas about NOS and some basic scientific concepts, we used Science Knowledge Survey (SKS). This test was originally developed by Flammer (1993). It was translated and adapted into Turkish by Doğan, Çakıroğlu, Bilican and Çavuş (2012). SKS included 25 items, some of which contained postmodern while others contained positivist views of science. The questions included two answer choices: "I agree" and "I don't agree." This test was applied before and after the intervention.Before the intervention we asked open ended questions to students about NOS themes such as the tentative nature of science, scientific knowledge is based on empirical evidence, subjective nature of science, and the role of imagination and creativity in science. The open-ended questions were based on the "Views of Nature of Science-D (VNOS-D)" instrument developed by Lederman and Khishfe (2002) and they were further validated through expert opinions. The VNOS-D questionnaire was applied after the intervention to facilitate the data collection procedure through open-ended questions.

Table 1. Data sources for the sub research questions

\begin{tabular}{ll}
\hline Sub questions & Data source \\
\hline \multirow{2}{*}{ 1. Sub question } & $\begin{array}{l}\text { Qualitative data (open ended questions prepared based on VNOS-D) + Science } \\
\text { Knowledge Survey (SKS) }\end{array}$ \\
\hline 2. Sub question & $\begin{array}{l}\text { Qualitative data (VNOS-D + open ended questions) + Science Knowledge } \\
\text { Survey (SKS) }\end{array}$ \\
\hline
\end{tabular}

Unstructured classroom observations were conducted during the nine-week intervention period to support the other data obtained in the study. One of the researchers acted as a participant observer. Field notes were taken 
during the observation sessions and they were rewritten in more detail immediately afterwards. The observer also included her reflections in the observation notes. Table 1 shows the data sources for the sub research questions.

\section{Application Procedure}

In this study, four different teaching approaches were used during the intervention to improve STs ideas about NOS and how to teach it. The intervention lasted nine weeks and during this time, STs completed various activities related to NOS. The purpose of the intervention was to help STs to use and learn various methods and activities to teach historical development of science, properties of scientific knowledge, and NOS. Table 2 shows the sequence of teaching applications during the nine weeks of application.

Table 2. Purpose and scope of the developed education program

\begin{tabular}{|c|c|c|}
\hline Weeks & Application & Purpose and scope \\
\hline $\begin{array}{l}1 . \\
\text { Week }\end{array}$ & $\begin{array}{l}\text { Science Knowledge Survey (Pre-test) } \\
\text { Collecting written comments about } \\
\text { scientific myths }\end{array}$ & $\begin{array}{l}\text { The purpose was creating a medium for discussing the relationship } \\
\text { among science, technology, and society so that we can determine } \\
\text { students' prior knowledge about these concepts. }\end{array}$ \\
\hline $\begin{array}{l}2 . \\
\text { Week } \\
\end{array}$ & $\begin{array}{l}\text { Nature and history of science through } \\
\text { the historical approach }\end{array}$ & \multirow{3}{*}{$\begin{array}{l}\text { The aim was helping STs to learn something about the history of } \\
\text { science, development of scientific information, and properties of } \\
\text { scientific knowledge. Students were asked to investigate various } \\
\text { scientists' contribution to science (for example: İbn-i Sina, Graham } \\
\text { Bell, Marie Cruie, Thomas Edison, Nicolas Tesla, Albert Einstein, } \\
\text { Stephen Hawking, Cahit Arf, Oktay Sinanoglu, Canan Dağdeviren, } \\
\text { Aziz Sancar). STs' presentations were critiqued based on their NOS } \\
\text { content. }\end{array}$} \\
\hline $\begin{array}{l}3 . \\
\text { Week }\end{array}$ & $\begin{array}{l}\text { Nature and history of science through } \\
\text { the historical approach }\end{array}$ & \\
\hline $\begin{array}{l}4 . \\
\text { Week }\end{array}$ & $\begin{array}{l}\text { Student groups' presentations of } \\
\text { scientists. }\end{array}$ & \\
\hline $\begin{array}{l}5 . \\
\text { Week }\end{array}$ & $\begin{array}{l}\text { Properties and nature of science } \\
\text { through generic activities } \\
\text { Fossilized footprints } \\
\text { Young and old women } \\
\text { What is in the tube? }\end{array}$ & $\begin{array}{l}\text { The purpose was helping STs learn about the following themes: } \\
\text { scientific knowledge is open to change, scientific knowledge is based } \\
\text { on evidence obtained through experiments and observations, } \\
\text { observations and inferences are different from one another, scientific } \\
\text { theories and laws are different types of knowledge, scientific } \\
\text { knowledge can be subjective, imagination and creativity have an } \\
\text { important role in science, scientific knowledge is influenced by social } \\
\text { and cultural norms. }\end{array}$ \\
\hline $\begin{array}{l}6 . \\
\text { Week }\end{array}$ & $\begin{array}{l}\text { Explicit - reflective method } \\
\text { Adventure of atomic models activity* } \\
\text { Which model? Atomic Models } \\
\text { activity* }\end{array}$ & $\begin{array}{l}\text { With the adventure of atomic models activity, we aimed STs to learn } \\
\text { about the atomic models' historical development and NOS themes at } \\
\text { the same time. } \\
\text { Which model? Atomic Models activity was aimed to show STs that } \\
\text { models are produced for a specific purpose, one model cannot explain } \\
\text { every situation or all natural events and they may change based on } \\
\text { new data and evidence. }\end{array}$ \\
\hline $\begin{array}{l}7 . \\
\text { Week }\end{array}$ & $\begin{array}{l}\text { Explicit - reflective method } \\
\text { Formation of Living } \\
\text { Organisms activity* } \\
\text { Nature of science through media news }\end{array}$ & $\begin{array}{l}\text { With the "Formation of Living Organisms" activity we expected STs } \\
\text { to learn about how the research about living things developed in time } \\
\text { and by looking at cases in science, learn about how scientific } \\
\text { knowledge can be distinguished from nonscientific knowledge. } \\
\text { We helped STs to critique news and situations that they can see on } \\
\text { media by using critical thinking skills. For this purpose we asked STs } \\
\text { to evaluate a news article based on the criteria provided to them. This } \\
\text { helped students to understand NOS and the structure of scientific } \\
\text { knowledge. }\end{array}$ \\
\hline & $\begin{array}{l}\text { Explicit - reflective method } \\
\text { Sky Adventure activity* } \\
\text { Earth's Shape and Rotation activity* } \\
\text { Nature of science through media news }\end{array}$ & $\begin{array}{l}\text { The Sky Adventure activity was used to help STs to learn about sun, } \\
\text { shapes, sizes, distances of the earth and the moon, and at the same } \\
\text { time about NOS themes. Students compared sizes, shapes, and } \\
\text { distances between the earth and the moon using the models that they } \\
\text { developed. } \\
\text { Earth's Shape and Rotation activity was used to help STs to evaluate } \\
\text { evidences of earths shape and rotation obtained from photographs of } \\
\text { stars taken from earth and also to help them understand that science is } \\
\text { based on observations and evidence and observations and inferences } \\
\text { are different from each other. }\end{array}$ \\
\hline $\begin{array}{l}9 . \\
\text { Week }\end{array}$ & $\begin{array}{l}\text { Nature of science through media news } \\
\text { Science Knowledge Survey (Post-test) } \\
\text { VNOS-D (Post-test) }\end{array}$ & $\begin{array}{l}\text { Students were asked to discuss their prior knowledge about NOS and } \\
\text { their current understanding of NOS. }\end{array}$ \\
\hline
\end{tabular}

*These activities were obtained from the book titled "Teaching Nature of Science through Activities" which was prepared as part of the "Bidomeg" project (Yalaki, 2016) 
Since STs are going to provide education in the elementary level, we focused on NOS themes that are appropriate for his level (Lederman \& Lederman, 2005). The targeted themes at this level were: (1) tentative nature of scientific knowledge, (2) scientific knowledge is based on observations and experiments, (3) subjective nature of scientific knowledge, and (4) importance of imagination and creativity in science.

Table 3. Distribution of activities based on the targeted NOS themes

\begin{tabular}{lccccc}
\hline Activities & Themes & $\begin{array}{l}\text { Scientific knowledge } \\
\text { is tentative }\end{array}$ & $\begin{array}{l}\text { Based on experiment } \\
\text { and observation }\end{array}$ & $\begin{array}{l}\text { Subjective nature } \\
\text { of science }\end{array}$ & $\begin{array}{l}\text { Importance of creativity } \\
\text { and imagination }\end{array}$ \\
\hline Fossilized footprints & + & + & + & + & + \\
\hline Young and old women & + & + & + & + \\
\hline What is in the tube? & + & + & & + \\
\hline $\begin{array}{l}\text { Adventure of Atomic } \\
\text { Models activity }\end{array}$ & + & + & & + \\
\hline $\begin{array}{l}\text { Which model? Atomic } \\
\text { models activity }\end{array}$ & + & + & & + \\
\hline $\begin{array}{l}\text { Formation of Living } \\
\text { Organisms activity }\end{array}$ & + & + & + & + \\
\hline Sky Adventure activity & + & + & + & + \\
\hline $\begin{array}{l}\text { Earth's Shape and } \\
\text { Rotation activity }\end{array}$ & + & + & & + \\
\hline
\end{tabular}

\section{Data Analysis}

The quantitative data obtained during the study was analyzed using the SPSS 21.0 (Scientific Package for Social Sciences) software program. The data obtained through the SKS instrument was marked as "1" if correct and "0" if otherwise. We used descriptive statistic and dependent samples t-test for data analysis. Data obtained from open-ended questions and open-ended questions were analyzed by content analysis and descriptive analysis techniques. For coding the data, a rubric developed by Lederman and Holiday (2011) and adapted and translated into Turkish by Yalaki and Çakmakçı (2011) was used (Appendix 1). Data obtained from the openended questions and the VNOS-D questionnaire was grouped into three categories based on this rubric. Students who had inadequate views of NOS were categorized as "naive," those who had acceptable but incomplete views of NOS were categorized as "transition," and those who had adequate views of NOS were categorized as "informed". The data obtained from classroom observations were analyzed descriptively. In the descriptive analyses, the data are summarized based on the predetermined themes (Yıldırm \& Şimşek, 2015). Nature of science themes were considered for analyzing the observation notes in order to support the other findings in this study.

\section{Results}

This section presents qualitative and quantitative findings under separate titles. The qualitative findings obtained from the open-ended questions prior to intervention and open-ended questions with VNOS-D after the intervention are presented according to the targeted themes of NOS. The findings obtained from the SKS are presented under the title of the quantitative findings.

\section{Qualitative Findings}

\section{The Tentative Nature of Scientific Knowledge}

Prior to the intervention, $67 \%$ of the STs had an inadequate understanding on the tentative nature of scientific knowledge, whereas $33 \%$ of the participants had views in the transition category. Before the intervention, $67 \%$ of the STs thought that scientific knowledge is absolute and does not change; change in scientific knowledge is associated with technological advancement; and current scientific knowledge is valid everywhere. On the other hand, $33 \%$ of the participants stated that scientific knowledge is tentative, but could not explain and exemplify it. Thus, those individuals were included in the transition category. It was determined that the STs did not have an informed understanding on the tentative nature of scientific knowledge before the intervention. Some STs' views about the tentative nature of scientific knowledge before the intervention are presented below. 
The views in the naive category:

- Scientific knowledge is proven to be right. It is absolute.

- Scientific knowledge is absolute and accepted by everybody. It is objective and testable.

- Scientists generate scientific knowledge, which does not change in the future.

- Scientific knowledge is required to be proven. It refers to universal phenomena accepted by everybody. It does not change from person to person.

The views in the transition category:

- Scientific knowledge can change in the future. Science is open to novelty and development.

- Science pursues certainty, but changes occur in science as well.

- Scientific knowledge changes and develops along with technological developments.

The views in the informed category:

- Scientific knowledge develops day by day. It is based on experiment, research and evidence. What differs scientific knowledge from other disciplines most importantly is its evidence-based nature. Science is falsifiable, or scientific knowledge is tentative.

- Scientific knowledge is based on empirical evidence. What makes it different from other disciplines is its cumulative progress. There is no science without evidence. Any new knowledge can change a previous one.

After the intervention, $6 \%$ of the STs had an inadequate understanding on the tentative nature of scientific knowledge; $65 \%$ of the participants held transitional views; and $29 \%$ of them had an informed understanding on science. The comparison of the qualitative data obtained before and after the intervention shows that the percentage of the individuals having an inadequate understanding largely decreased, while the percentages of those in the transition and informed categories substantially increased. After the intervention, the STs stated that scientific knowledge is subject to change based on new findings and results of scientific research and technological advancement. They also stated that scientific knowledge is durable but never certain and absolute and it is tentative through reconsideration of the current data and evidence. These findings indicate that STs' views about the tentative nature of scientific knowledge changed positively. Some STs' views about the tentative nature of scientific knowledge after the intervention are presented below.

The views in the transition category:

As technology and opportunities develop, scientific knowledge may change. Scientists can find the deficiencies and mistakes in the work done. For example, it was accepted for centuries that the earth is flat, but then it was proved that it is actually round.

The views in the informed category:

Scientists produce knowledge by reinterpreting the data they obtain as a result of experiment and systematic observation. Knowledge may change in the future with the development of knowledge and the re-interpretation of the current data with the emergence of new data.

Scientific knowledge may change in the future because scientists can access new information by reinterpreting the previous scientific knowledge, or they can refute the old knowledge with the new information. 
I think that scientific knowledge may change because scientific knowledge is never absolute although it has a reliable and durable structure. It is tentative and open to change. It may be changed through tests and re-evaluations. It is open to criticism. For example, transition occurred from Newtonian physics to Einstein physics.

Scientific knowledge may change in the future because there is no one-hundred-percent certainty in science. Knowledge changes as new evidence is obtained from on-going research, experiments, and observations. For example, it was thought that cancer could not be destroyed by a precise solution. Now this knowledge has changed with the knowledge provided Aziz Sancar.

Considering the findings obtained before and after the intervention, it can be said that the activities used in this study were effective in changing the views of the STs about the tentative nature of scientific knowledge. This finding is also supported by the classroom observations. In pre-class discussions, most of the STs claimed that scientific knowledge does not change. They gave evidence based on their prior learning, e.g., "law of gravity does not change". After the intervention, there was a considerable increase in the number of students holding views regarding tentative nature of scientific knowledge.

\section{Dependence of Scientific Knowledge on Experimental Evidence}

Before the intervention, $65 \%$ of the STs had an inadequate perspective on the dependence of scientific knowledge on experimental evidence, whereas $35 \%$ of them had transitional views. These results indicate that before the intervention, $65 \%$ of the STs thought that science is a collection of proved knowledge, an objective endeavor and a search of proved facts. $35 \%$ of the participants, on the other hand, considered that science is based on experimental evidence, but could not explain and exemplify it. Thus, those individuals were included in the transition category. STs did not have a developed perspective on the dependence of science on experimental evidence. Some STs' views about the dependence of scientific knowledge on experimental evidence before the intervention are presented below.

The views in the naive category:

Scientific knowledge is an aggregate of knowledge that is objective, observable, measurable, identifiable, advancing, self-developing, and accepted valid by everyone.

The views in the transition category:

Scientific knowledge is obtained based on experimental evidence. Observations and experiments are in the foreground. It is provable. It is concrete.

Scientific knowledge is obtained through observations and experiments.

Science depends on experiment. Thinking is not enough alone. Evidence is important in science.

Scientific knowledge is concrete knowledge obtained through research and observation.

Scientific knowledge is obtained using a scientific method. In other words, evidence is collected. It progresses cumulatively. It is objective. Scientific knowledge is based on evidence. What makes it different from other disciplines is its cumulative progress. There is no science without evidence. Any new knowledge can change a previous one.

The views in the informed category:

Scientific knowledge is produced by experimentation and observation. Reasonable and logical solutions are developed. 
Scientific knowledge is based on experimentation and observation. It arises as a result of certain research. Science incorporates a process depending on experimentation. There is no one-hundredpercent truth.

After the intervention, $8 \%$ of the STs had an inadequate perspective on the dependence of scientific knowledge on experiment and observation; $61 \%$ of the participants had transitional views; and $31 \%$ of them had a developed perspective on science. Majority of the STs $(61 \%)$ had transitional views with regard to the dependence of scientific knowledge on evidence. The individuals included in the transition category stated that science is based on experimental evidence, but they did not express that scientific knowledge is never proved absolutely. This is why they were included in this category. The individuals in the informed category stated that science depends not only on experimental evidence but involves reasoning and logical inference as well; it depends on direct or indirect observation of the world; and scientific knowledge can never be proved absolutely.

The comparison of the qualitative data obtained before and after the intervention shows that the percentage of the individuals in naïve category largely decreased, while the percentages of those in the transition and informed categories substantially increased. It was determined that the views about the dependence of scientific knowledge on experimental evidence changed positively. Some STs' views about the dependence of scientific knowledge on experimental evidence after the intervention are presented below.

The views in the transition category:

Knowledge is produced using different scientific methods. Hypotheses are formulated and they are accepted or rejected by further observations and experiment results. New knowledge is obtained as a result of long-term studies, experiments, and observations.

Scientific knowledge is produced through experiment, observation, inquiry and discussion. Knowledge is produced by inquiry. It is generated through integration of the old and the new knowledge. Scientists make observations and experiments, question new information using their prior knowledge, and thereby construct new knowledge or refute the existing one.

The views in the informed category:

Knowledge is produced through research, observation, and experiment. Scientists reach new knowledge through experiment, observation, and inference.

In natural sciences, knowledge is generated through imagination, research, inquiry, and discussion. Scientists attain knowledge by wondering it and using their imagination.

The findings obtained before and after the intervention demonstrate that the STs' view about the dependence of scientific knowledge on experimental evidence improved.

\section{Subjectivity of Scientific Knowledge}

Before the intervention, $74 \%$ of the STs had an inadequate perspective on the subjectivity of scientific knowledge, whereas $25 \%$ of the participants had transitional views and $1 \%$ had informed views. According to these results, before the intervention, $74 \%$ of the STs thought that scientists are objective, and they cannot be subjective. $25 \%$ of the participants, on the other hand, said that scientists could have different views and ideas, but could not explain or exemplify it at a satisfactory level. Thus, those individuals were included in the transition category. $1 \%$ of the STs thought that scientists' prior knowledge, experience, and education will affect their work, and their creativity and imagination may play a role in their inferences, thereby leading to different thoughts. In this way, they demonstrated a more developed perspective on science and they were included in the informed category. Some STs' views about the subjectivity of scientific knowledge before the intervention are presented below. 
The views in the naive category:

What makes scientific knowledge different from other disciplines is its objectivity, true objectivity. Scientific knowledge is certain. Individuals' views do not change.

Scientific knowledge is objective. The most important feature making science different from other disciplines is its objectivity.

Scientific knowledge is required to be proved. It refers to universal phenomena accepted by everybody. It does not change from person to person.

Scientific knowledge is an aggregate of knowledge that is objective, observable, measurable, identifiable, advancing, self-developing, and accepted valid by everyone.

The views in the informed category:

Scientific knowledge is subjective. This is because it is affected by the education and experience of the person engaged in it. This is why different views come out.

After the intervention, $13 \%$ of the STs had an inadequate perspective on the subjectivity of scientific knowledge, whereas $23 \%$ of the participants had transitional views and $64 \%$ of them had informed views. The comparison of the qualitative data obtained before and after the intervention shows that the percentages of the individuals in the naive and transition categories largely decreased, while the percentage of those in the informed category substantially increased. It was determined that after the intervention, majority of the STs (64\%) thought that the theories scientists believe in as well as their values, beliefs, prior knowledge and experience, education, and expectations will affect their works; their creativity and imagination may play a role in their inferences; and all this can lead to different views. Thus, the individuals in this group were found to have a more postmodern perspective on science. It was found out that the views about the subjectivity of scientific knowledge improved. Some STs' views about the subjectivity of scientific knowledge after the intervention are presented below.

The views in the naive category:

This is because the current situations and events date back to very old times. Science has an idea about the existence of dinosaurs because scientists can prove it. However, what they were has not been presented by science objectively and with common evidence yet. That is, the reason is lack of data.

The views in the transition category:

This is because everybody is just expressing their own views.

The views in the informed category:

Scientists make different inferences based on the same knowledge. Knowledge is affected by scientists' personal characteristics, creativity, and social, political, and cultural values surrounding them. Scientific knowledge is subjective.

Scientific knowledge is subjective. Scientists put forward different ideas about a subject based on their imagination, belief, social and cultural background, experience, and education. Although they have the same data, they have different views because they are different from each other.

Comparison of findings obtained before and after the intervention reveals development of STs' views regarding subjectivity of nature of scientific knowledge. In addition, observation results support this finding. At the beginning of the intervention, STs viewed science as an objective endeavor. They supported their claim as, "If 
it is not totally objective, it is not science". After the student groups' presentations of scientists, they recognized science as a human activity and understood that science is not an endeavor which is fully objective.

\section{Role of Imagination and Creativity in Science}

Before the intervention, $97 \%$ of the STs had an inadequate perspective on the role of imagination and creativity in science, whereas $3 \%$ of them held transitional views. These results indicate that before the intervention, almost all of the STs (97\%) thought that imagination and creativity have no influence on the generation of scientific knowledge. They thought that scientific method is definite and certain; and so there is no need for imagination and creativity. $3 \%$ of the STs, on the other hand, stated that imagination and creativity play a part in the production of scientific knowledge, but they did not explain and exemplify it. This is why they were included in the transition category. As in other NOS themes, most STs had an inadequate perspective on the role of imagination and creativity in science. None of the STs fell under the informed category in this theme. Some STs' views about the role of imagination and creativity in science before the intervention are presented below.

The views in the naive category:

Scientific knowledge is obtained by using scientific methods. It is universal and absolute. Scientific knowledge is obtained using a scientific method.

Scientific knowledge is obtained through certain methods. Data and evidences are collected. Then the obtained data are interpreted.

Scientific knowledge is obtained through scientific methods. It is obtained through experiment and proving.

The views in the transition category:

Scientific knowledge is obtained as a result of curiosity and research. In this process, scientists imagine. They design and conduct different experiments. They obtain the results by trial and error.

Scientists discover scientific knowledge through experimental and logical ways. They decided by reasoning.

After the intervention, 5\% of the STs had an inadequate perspective on the role of imagination and creativity in science, whereas $80 \%$ of the participants had views in the transition category and $15 \%$ of them were in the informed category.

The comparison of the qualitative data obtained before and after the intervention shows that the percentage of the individuals having an inadequate perspective largely decreased, while the percentages of those in the transition and informed categories substantially increased. After the intervention, majority of the STs stated that imagination and creativity are influential on obtaining scientific knowledge, but they did not explain or exemplify at a satisfactory level. Also, they said that imagination and creativity can be used in some stages of the production of scientific knowledge. $15 \%$ of the STs stated that scientists' imagination and creativity are influential on obtaining scientific knowledge and having different views on scientific knowledge; imagination and creativity are influential on every stage of the production of scientific knowledge; and there is no single scientific method for the production of scientific knowledge. As a result, it was found that the views about the role of imagination and creativity in obtaining scientific knowledge improved, but not at a sufficient level, given the small number of individuals in the informed category. Some STs' views about the role of imagination and creativity in the process of obtaining scientific knowledge after the intervention are presented below.

The views in the transition category:

They are used in the stage of interpretation. For example, when modeling, scientists make what is invisible visible by using their imagination. Creativity and imagination are not used in experiment and observation. Scientists describe the idea or model they have created in the stage of reporting, 
during which they use their creativity. Creativity and imagination are used in the stage of planning, as well.

Scientists use their imagination and creativity in the observation and interpretation stages of their research. This is because they are subjective stages. They depend on how a person looks. Therefore, imagination and creativity come into play in these stages.

They use their imagination and creativity in the stage of interpretation. They make comments about the causes at the end of their observations. However, every scientist has a unique creativity and can explain the causes of their observations in a different way. For instance, different scientists provided different interpretations about the causes of the extinction of dinosaurs.

Scientists use their imagination and creativity from the initial to the final stage of their research. As a matter of fact, the most important factors influential on search of knowledge are curiosity and imagination.

The views in the informed category:

If scientists did not use their imagination, we would not have most of the inventions we use today. Imagination is like the seed of inventions.

Scientists use their imagination and creativity in every stage of their research. They use them from the identification of research problems to the interpretation of the results obtained.

Imagination is needed in every stage of research because they try to find something which has not existed until then. Finding the unknown requires creativity and imagination.

The findings obtained before and after the intervention demonstrate that the STs' views about the role of imagination and creativity in obtaining scientific knowledge improved. Data obtained from classroom observations support this finding. In the early weeks of intervention, STs emphasized that observation and experiment were sufficient to provide scientific knowledge. They underestimated the role of imagination and creativity as a role in the production of scientific knowledge. Towards the end of the intervention, especially after the atomic models activity, STs noticed that scientific knowledge involves scientist's creativity and imagination.

Table 4 presents the results before and after the intervention. Majority of the STs had an inadequate perspective on NOS before the intervention. However, the percentage of the individuals with an inadequate perspective largely decreased, and the percentages of those with views falling into the transition and informed categories substantially increased after the intervention. It was determined that the views of majority of the STs about these themes had changed and improved by the end of the intervention.

Table 4. Frequency of the individuals in categories before and after intervention for each NOS theme

\begin{tabular}{lcccc}
\hline \multicolumn{1}{c}{ The Themes of NOS } & & Naive & Transition & Informed \\
\hline \multirow{2}{*}{ The tentative nature of scientific knowledge } & Before & $67 \%$ & $33 \%$ & $0 \%$ \\
\cline { 2 - 4 } & After & $6 \%$ & $65 \%$ & $29 \%$ \\
\hline \multirow{2}{*}{$\begin{array}{l}\text { The dependence of scientific knowledge on } \\
\text { experimental evidence }\end{array}$} & Before & $65 \%$ & $35 \%$ & $0 \%$ \\
\cline { 2 - 5 } The subjectivity of scientific knowledge & After & $8 \%$ & $61 \%$ & $31 \%$ \\
\hline \multirow{2}{*}{ The role of imagination and creativity in science } & Before & $76 \%$ & $23 \%$ & $1 \%$ \\
\cline { 2 - 5 } & After & $13 \%$ & $23 \%$ & $64 \%$ \\
\cline { 2 - 5 } General View & Before & $97 \%$ & $3 \%$ & $0 \%$ \\
\cline { 2 - 5 } & After & $5 \%$ & $80 \%$ & $15 \%$ \\
\hline
\end{tabular}

\section{Quantitative Findings}

Comparison of the Pre-Test and Post-Test Scores From the SKS 
The SKS was administered to the STs as a pre-test and as a post-test. The data obtained from the SKS had a normal distribution and an analysis was done through dependent t-test to reveal whether there was a difference between the pre-test and post-test scores. The dependent t-test results concerning the mean pre-test and post-test scores are presented in Table 5.

Table 5. The dependent sample t-test results of the SKS

\begin{tabular}{|c|c|c|c|c|c|c|c|}
\hline The Themes of NOS & & Mean & $\mathbf{n}$ & Std. Deviation & $\mathbf{p}$ & df & $\mathbf{t}$ \\
\hline \multirow{2}{*}{$\begin{array}{l}\text { The tentative nature of } \\
\text { scientific knowledge }\end{array}$} & Pre-test & 0.55 & 48 & 0.2360 & \multirow{2}{*}{$0.00 *$} & \multirow{2}{*}{43} & \multirow{2}{*}{-3.362} \\
\hline & Post-test & 0.66 & 48 & 0.2382 & & & \\
\hline \multirow{2}{*}{$\begin{array}{l}\text { The dependence of scientific } \\
\text { knowledge on evidence }\end{array}$} & Pre-test & 0.51 & 48 & 0.1529 & \multirow{2}{*}{$0.028 *$} & \multirow{2}{*}{46} & \multirow{2}{*}{-5.002} \\
\hline & Post-test & 0.63 & 48 & 0.1141 & & & \\
\hline \multirow{2}{*}{$\begin{array}{l}\text { The subjectivity of scientific } \\
\text { knowledge }\end{array}$} & Pre-test & 0.35 & 48 & 0.3444 & \multirow{2}{*}{$0.04^{*}$} & \multirow{2}{*}{46} & \multirow{2}{*}{-5.291} \\
\hline & Post-test & 0.64 & 48 & 0.3410 & & & \\
\hline \multirow{2}{*}{$\begin{array}{l}\text { The role of imagination and } \\
\text { creativity in science }\end{array}$} & Pre-test & 0.77 & 48 & 0.4247 & \multirow{2}{*}{$0.038^{*}$} & \multirow{2}{*}{47} & \multirow{2}{*}{-1.952} \\
\hline & Post-test & 0.89 & 48 & 0.4087 & & & \\
\hline \multirow{2}{*}{ General View } & Pre-test & 0.54 & 48 & 0.1638 & \multirow{2}{*}{$0.007 *$} & \multirow{2}{*}{45} & \multirow{2}{*}{-6.731} \\
\hline & Post-test & 0.71 & 48 & 0.1404 & & & \\
\hline
\end{tabular}

$*$ Mean differences are significant at the 0.05 level.

The STs had a mean score of 54 out of 100 in the SKS as a pre-test and a mean score of 71 out of 100 in the SKS as a post-test, which refers to a rise of $40 \%$ in the mean score of the STs through the intervention. The pvalue calculated at the end of the analyses, with a confidence interval of $95 \%(\mathrm{p}<0.05)$, indicates that there is a statistically significant difference between the pre-test and post-test scores achieved by the STs in the SKS $[\mathrm{t}(45)=-6,731 ; \mathrm{p}<0.05]$. According to the Table 5, there are statistically significant differences between the STs' mean pre-test and post-test scores in each theme of NOS.

These results show that the learning approaches and activities used during the intervention were effective in improving the STs' views about the targeted NOS themes. These results are in agreement with the qualitative data provided above. The various data sources used in this study, which included open-ended questions, observation notes and the SKS instrument provided evidence that were in mutual agreement. This triangulation of evidence improves the validity of the findings.

\section{Discussion and Conclusion}

This study attempted to improve the STs' views about NOS through teaching NOS based on a multi approach extensive intervention. Before the intervention, the STs held beliefs that can be categorized as myths about science, such as science is only based on data obtained through experiments and observations; imagination and creativity are not effective in the production of scientific knowledge; scientific knowledge is absolute, objective, and unchangeable. All these perceptions are a result of a naïve positivist science view, since these individuals have gone through an educational process dominated by such views.

The qualitative and quantitative data obtained before the intervention support each other. Before the intervention, the STs were found to have inadequate perspectives on NOS and to hold some misconceptions. Prior to the intervention, majority of the STs were determined to have an inadequate perspective on the themes of NOS. This result is in agreement with findings from other studies in the literature (Abd-El-Khalich \& Akerson, 2004; Abd-El-Khalich \& Boujaoude, 1997; Dagher \& BouJaoude, 1997; Dagher et al., 2004; Doğan et al., 2008; Köseoglu, Tümay \& Üstün, 2010; Lederman, 1992; Macaroğlu et al., 1998; McComas, 2000; Norris \& Phillips, 1994; Saraç, 2012; Shiang-Yao \& Lederman, 2002, 2007; Tatar et al., 2011a; Taşar, 2003). One of the reasons why STs consistently have inadequate understanding of NOS may be the existence of common misconceptions of science in textbooks and other resources in science education (McComas, 2000). The misconceptions of STs about NOS are formed during their elementary and secondary education throughout the years and the misrepresentation of NOS during this education plays an important role in the formation of their NOS views (İrez, 2009).

At the end of the intervention, the STs' views about NOS improved toward a contemporary view of science in the light of postmodern discussions. It was determined that the practices involved during the intervention in teaching certain NOS themes improved the STs' views about NOS. Research in this area advised that inadequate views of NOS cannot be changed to the "informed level" in a short period of time; since it is not 
easy to change STs' views which they internalized during their prior education over the years (Lederman, 2007; McComas, 2008). The nine-week-long applications in this study had a significant influence on the STs' views about NOS. During this period, STs had a chance to discuss various aspects of NOS and evaluate their own views as well as their peers' views. In the end, their views about the targeted four themes of NOS improved significantly.

Doğan, Çakıroğlu, Çavuş, Bilican \& Arslan (2011) obtained a similar result on an in-service education program that helped science teachers develop their views of NOS over a long intervention. Especially interventions that involve explicit-reflective approaches are effective in improving students', STs', and teachers' NOS views (Abd-El-Khalick \& Lederman, 2000; Khishfe \& Abd-El-Khalick, 2002; Khishfe \& Lederman, 2007; Çavuş, 2010; Köseoğlu, Tümay \& Budak, 2008; Schwartz, Lederman \& Crawford, 2004). Abd-El-Khalick \& Lederman (2000) suggested that interventions that involve historical approach with explicit-reflective approaches may be more effective in teaching NOS. Using different approaches together over sufficient time periods seems to be a good way for improving STs’ NOS views (Tuan \& Chin, 1999).

As a result, in this study, both the quantitative and the qualitative findings indicated the positive influence of the practices involving a variety of activities on the improvement of the STs' views about NOS. It can be said that change in the perspectives of NOS requires sufficient time, and use of different activities.

\section{Recommendations}

The present study involved the development and application of four different teaching approaches for teaching NOS. With four different approaches adopted, an attempt was made to appeal to all of the participants. For further study, STs may be followed in their classroom practices to assess how they utilize their knowledge of NOS in teaching.

\section{References}

Abd-El-Khalick, F. (2002). The influence of a philosophy of science course on pre-service secondary science teachers' views of nature of science, Proceedings of 2002 The Annual International Conference of The Association for the Education of Teachers in Science.

Abd-El-Khalick, F. \& Akerson, V. (2004). Learning as conceptual change: factors mediating the develop-ment of preservice elementary teachers' views of nature of science. Science Education, 88(5), 785-810.

Abd-El-Khalick, F.,\& BouJaoude, S. (1997). An exploratory study of the knowledge base for science teaching. Journal of Research in Science Teaching, 34(7), 673-699.

Abd-El-Khalick, F. \& Lederman, N. G. (2000). Improving science teachers' conceptions of the nature of science: A critical review of the literature. International Journal of Science Education, 22(7), 665-701.

American Association for the Advancement of Science [AAAS]. (1990). Science for all Americans. New York: Oxford University Press.

Aslan, O., Yalçın, N., \& Taşar, M. F. (2009). Fen ve teknoloji öğretmenlerinin bilimin doğası hakkındaki görüşleri. Ahi Evran Üniversitesi Eğitim Fakültesi Dergisi, 10(3), 1-8

Bell, R., Blair, M., Crawford, B., \& Lederman, N. (2003). Just do it? Impact of a science apprenticeship program on high school students' understanding of nature of science and scientific inquiry. Journal of Research in Science Teaching, 40, 487-509.

Bell, R. L., Lederman, N. G., \& Abd-El-Khalick, F. (2000). Developing and acting upon one's conception of the nature of science: a follow-up study, Journal of Research in Science Teaching, 37, 563-581.

Creswell, J. W., \& Miller, D. L. (2000). Determining validity in qualitative inquiry. Theory into Practice, 39(3), 124-130.

Creswell, J. W., \& Plano Clark, V. L. (2011). Designing and conducting mixed methods research (2nd ed.). ThousandOaks, CA: Sage.

Çakmakçı, G., \& Yalaki, Y. (2012). Promoting student teachers' ideas about nature of science through popular media. Trondheim, Norway: S-TEAM/NTNU.

Çavuş, S. (2010). Illkögretim fen bilgisi ve matematik öğretmenliği lisans ögrencilerinin bilimin doğası hakkındaki görüşlerinin geliştirilmesi. Yayımlanmamış Yüksek Lisans Tezi. Abant İzzet Baysal Üniversitesi

Çepni S. (2011). Kuramdan uygulamaya fen ve teknoloji öğretimi. Ankara; Pegem Akademi.

Dagher Z. R., \& BouJaoude S. (1997). Scientific views and religious beliefs of college students: The case of biological evolution. Journal of Research in Science Teaching, 34, 583-590. 
Dagher Z. R., Brickhouse N., Shipman H., \& Letts W. (2004). How some college students represent their understanding of scientific theories. International Journal of Science Education, 26, 735-755.

DeBoer, G. E. (2000). Scientific literacy: Another look at its historical and contemporary meanings and its relationship to science education reform. Journal of Research in Science Teaching, 37, 582-601.

Doğan, A., Akçay, H., Kaya, O. \& Öcal E. (2008).İlköğretim öğrencilerinin bilim insanı hakkındaki görüşleri (özet Kitab1). VIII. Ulusal Fen Bilimleri ve Matematik Eğitimi Kongresi (s.140). Bolu Abant İzzet Baysal Üniversitesi Eğitim Fakültesi.

Doğan, N., \& Abd-El-Khalick, F. (2008). Turkish grade 10 students' and science teachers' conceptions of nature of science: A national study. Journal of Research in Science Teaching, 45(10), 1083-1112.

Doğan, N., Çakıroğlu, J., Bilican, K. \& Çavuş, S. (2012). Bilimin doğası ve ögrretimi (2. Baskı.). Ankara: Pegem Akademi.

Doğan N., Çakıroğlu J., Çavuş S., Bilican K. \& Arslan O. (2011). Öğretmenlerin bilimin doğası hakkındaki görüşlerinin geliştirilmesi: Hizmetiçi eğitim programının etkisi. Hacettepe Üniversitesi Ĕ̆itim Fakültesi Dergisi, 40, 127-139.

Flammer, L. (1993). Teaching the nature of science: A sample unit plan for high school biology. Science knowledge survey. Retrieved March 20, 2016, from

http://www.indiana.edu/ ensiweb/lessons/Sci.Know.Surv7.pdf

İrez, S. (2009). Nature of science as depicted in Turkish biology textbooks. Science Education, 93, $422-447$.

Khishfe, R. (2008). The development of seventh graders' views of nature of science. Journal of Research in Science Teaching, 45(4), 470-496.

Khishfe, R.,\& Abd-El-Khalick, F. (2002). Influence of explicit and reflective versus implicit inquiry-oriented instruction on sixth graders' views of nature of science. Journal of Research in Sclence Teaching, 39(7), $551-578$

Köseoğlu, F., Tümay H., \& Budak E. (2008). Bilimin doğası hakkında paradigma değişimleri ve öğretimi ile ilgili uygulamalar. Gazi Üniversitesi Gazi Ĕ̈itim Fakültesi Dergisi, 28(2), 221-237.

Köseoğlu, F., Tümay, H., \& Üstün, U. (2010). Bilimin doğası öğretimi mesleki gelişim paketinin geliştirilmesi ve öğretmen adaylarına uygulanması ile ilgili tartışmalar. Ahi Evran Üniversitesi Kırşehir Ĕ̆itim Fakültesi Dergisi, 11(4), 129-162.

Lederman, N. G. (1992). Students' and teachers' conceptions of the nature of science: A review of the research. Journal of Research in Science Teaching, 29(4), 331-359.

Lederman, N. G. (2007). Nature of science: past, present, and future. In S. K. Abell, \& N. G. Lederman (Ed.), Handbook of research on science education (p. 831-879). London: Lawrence Erlbaum Associates.

Lederman, N. G., Abd-El-Khalick, F., Bell, R. L., \& Schwartz, R. S. (2002). Views of nature of science questionnaire: Toward valid and meaningful assessment of learners conceptions of nature of science. Journal of Research in Science Teaching, 39, 497-521.

Lederman J. S., \& Holliday G. (2011). Young children's views of science scoring guide. Unpublished paper: Illinois Institute of Technology, Chicago, IL.

Lederman, J. S., \& Khishfe, R. (2002). Views of nature of science, Form D. Unpublished paper. Illinois Institute of Technology, Chicago, IL.

Lederman, J. S., \& Lederman, N. G. (2005). Developing and assessing elementary teachers' and students' understandings of nature of science and scientific inquiry. Paper presented at the annual meeting of the National Association for Research in Science Teaching, Dallas, TX.

Lincoln, Y., \& Guba, E. (1985). Naturalistic inquiry. Newbury Park: Sage Publications.

Macaroglu, E., Taşar, M. F. \& Cataloglu, E. (1998). Turkish preservice elementary school teachers' beliefs about the nature of science. Annual Meeting of National Association for Research in Science Teaching (NARST), San Diego, CA.

Matthews, M. (1996). The nature of science and science teaching. International Handbook of Science Education, 981-999,

McComas, W. (1996). Ten myths of science: Reexamining what we think we know about the nature of science, School Science and Mathematics, 96, 10-16.

McComas, W. F. \& Olson, J. K. (1998). International science education standards documents. In W. F. McComas (Ed.), The nature of science in science education rationales and strategies (p. 41-52). Dordrecht: Kluwer Acedemic Puslishers.

McComas, W. F., Clough, M. P. \& Almazroa, H. (2000). The role and the character of the nature of science. In W. F. McComas (Eds.), The nature of science in science education: Rationales and strategies, (p. 331350). Dordrecht: Kluwer Academic Publishers.

Mccomas, W. F. (2000). The principal elements of the nature of science: Dispelling the myths. In W. F. McComas (Ed.), The nature of science in science education: Rationales and strategies. Dordrecht: The Netherlands: Kluwer Academic Publishers. 
McComas, W. F. (2008). Seeking historical examples to illustrate key aspects of the nature of science. Science \& Education, 17, 249-263.

McMillan, J., \& Schumacher, S. (1997). Research in education: A conceptual introduction. (4th ed.). New York: Addison Wesley Longman, Inc.

Michel, H., \& Neumann, I. (2016). Nature of science and science content learning. Science \& Education, 25(910), 951-975.

Ministry of National Education [MNE] (2013). İlköğretim kurumlarl (ilkokullar ve ortaokullar) fen bilimleri dersi (3, 4, 5, 6, 7 ve 8. Sinıflar) öğretim programı. Ankara: Talim ve Terbiye Kurulu Başkanlığı.

Ministry of National Education [MNE] (2018). Ilköğretim kurumları (ilkokullar ve ortaokullar) fen bilimleri dersi (3, 4, 5, 6, 7 ve 8. Sinıflar) ögretim programı. Ankara: Talim ve Terbiye Kurulu Başkanlığı.

National Research Council [NRC] (2012). A framework for K-12 science education: practices, crosscutting concepts, and core ideas. Washington, DC: National Academies Press.

Norris S. \& Phillips L. (1994). Interpreting pragmatic meaning when reading popular reports of science. Journal of Research in Science Teaching, 31, 947-967.

Ochanji, M. (2003). Learning to teach the nature of science: A study of preservice teachers. Science Teaching Dissertation. Retrieved April 20, 2017, from https://surface.syr.edu/scied_etd/6

Organisation for Economic Co-operation and Development [OECD]. (2015). PISA 2015: Draft science framework. Retrieved April 18, 2017, from

https://www.oecd.org/pisa/pisaproducts/Draft\%20PISA\%202015\%20Science\%20Framework\%20.pdf

Saraç, E. (2012). Sınıf öğretmenleri ve sınıf öğretmeni adaylarının bilimin doğasına ilişkin görüşleri. Yayımlanmamış Yüksek Lisans Tezi. Akdeniz Üniversitesi, Antalya.

Schwartz, R. S., \& Lederman, N. G. (2002). It's the nature of the beast: The influence of knowledge and intentions on learning and teaching nature of science. Journal of Research in science teaching, 39(3), 205-236.

Schwartz, R. S., Lederman, N. G., \& Crawford, B. (2004). Developing views of nature of science in an authentic context: an explicit approach to bridging the gap between nature of science and scientific inquiry. Science Education, 88, 610-645.

Seçkin Kapucu, M., \& Çakmakçı, G. (2015). Belgesel filmlerin bilimin doğası, bilim tarihi ve kavram öğretiminde kullanılması. M. Sözbilir, \& A. Ayas (Ed.) Kimya öğretimi: Öğretmen eğitimcileri, öğretmenler ve öğretmen adayları için iyi uygulama örnekleri (s.725-750). Ankara: Pegem Yayıncılık.

Shiang-Yao, L., \& Lederman, N. G. (2002). Taiwanese gifted students' views of the nature of science. School Science and Mathematics, 102(3), 114-124.

Taşar, M. F. (2003). Teaching history and the nature of science in science teacher education programs. Pamukkale Üniversitesi Ĕ̈itim Fakültesi Dergisi, 7(1), 30-42.

Tatar, E., Karakuyu, Y., \& Tüysüz, C. (2011a). Sınıf öğretmeni adaylarının bilimin doğası kavramları hakkındaki yanlış anlamaları. Buca Ĕ̆itim Fakültesi Dergisi, 29, 153-161.

Tatar, E., Karakuyu, Y., \& Tüysüz, C. (2011b). Sınıf öğretmeni adaylarının bilimin doğası kavramları: Teori, yasa ve hipotez. Mustafa Kemal Üniversitesi Sosyal Bilimler Enstitüsü Dergisi, 8(15), 363-370.

Tolvanen, S., Jansson, J., Vesterinen, V.-M., \& Aksela, M. K. (2014). How to use historical approach to teach nature of science in chemistry education? Science \& Education, 23(8), 1605-1636.

Tuan, H. L., \& Chin, C. C. (1999). What can in-service Taiwanese science teachers learn and teach about the nature of science? The Annual Meeting of the National Association for Research in Science Teaching.

Yalaki, Y. \& Çakmakçı, G. (2011). Formative assessment to enhance students' learning of nature of science. 11th International History, Philosophy, Sociology \& Science Teaching Conference, Thessaloniki, Greece.

Yalaki, Y. (Ed.) (2016). Etkinliklerle bilimin doğasının öğretimi. Ankara: Pegem Akademi.

\begin{tabular}{lc}
\hline & Author Information \\
\hline Tuğba Ecevit & Yalcin Yalaki \\
Hacettepe University & Hacettepe University \\
Institute of Educational Sciences & Faculty of Education \\
Turkey & Turkey \\
Contact e-mail: tubaecevit@hacettepe.edu.tr & \\
Sevgi Kingir & \\
Hacettepe University & \\
Faculty of Education & \\
Turkey & \\
\hline
\end{tabular}




\section{Appendix. Rubric for scoring VNOS-D+ questionnaire (Adapted from Lederman \& Holliday, 2011)}

\begin{tabular}{ll}
\hline Tenets & \multicolumn{1}{c}{ Naive } \\
& - Perceive science as technology. \\
& Change in science equals \\
technological developments.
\end{tabular}

- Scientific knowledge can change (technological improvement aids change in science and scientific knowledge expands cumulatively).

- Scientific knowledge may be changed when experimental techniques improve, or new evidence is produced.

- Change as a result of new investigations and findings.

- Based on empirical evidence (no further elaboration)

- Based on experiments and/or direct observations.

- Scientific knowledge is durable but never absolute or certain. This knowledge, including theories and laws, is tentative and subject to change due to new evidence.

- Change can be evolutionary and revolutionary.

- Change may also occur as a result of re-conceptualization of current data.

- Scientific knowledge is, at least partially, based on and/or derived from observations of the natural world.

- Observations may be direct or indirect.

- Science does not rely solely on empirical evidence.

- Empirical evidence support rather than prove scientific knowledge.

- Scientific knowledge is subjective. Scientists' theoretical commitments, beliefs, previous knowledge, training, experiences, and expectations actually influence their work. Scientists' observations (and investigations) are always motivated and guided by, and acquire meaning in reference to questions or problems. These questions or problems, in turn,

- Science is subjective.

- Scientists may have different ideas. are derived from within certain theoretical perspectives (theoryladen).

- Creativity and imagination play a role in inferences.

- Scientists have different backgrounds and values which may lead to different interpretations of data and different conclusions. Because of this, one set of observations may lead to different and equally valid inferences.

- Imagination and creativity has no role in scientific activity.

- Scientists do not use imagination or creativity because imagination and/or creativity are in conflict with objectivity.

- Methods of science are certain and scientists do not need to imagine.

- Imagination and creativity are used while designing and innovating new technology.
- Scientific knowledge involves human imagination and creativity. The student does not elaborate her answer.

- Scientists use their imagination or creativity in some phases of their work, notably in designing experiments.
- Scientists use their imagination or creativity throughout their scientific investigations. Science involves the invention of explanations and this requires a great deal of creativity by scientists.

- Imagination and creativity play a role in all stages of scientific research.

- There is no single scientific method. 